\author{
Турчак Леся Іванівна, \\ кандидат мистеитвознавства, \\ Київський університет культури, \\ вул. С. Коновальия 36, Київ, Україна, 01133, \\ https://orcid.org/0000-0002-0490-8732, \\ lessit@ukr.net
}

\title{
ТВОРЧІСТЬ О. А. КОШИЦЯ У КОНТЕКСТІ СВІТОВОГО МИСТЕЦТВА
}

Мета статті. 3'ясувати місце і роль творчості О. Кошиця в контексті світової культури. Методологія. Полягає у використанні загальнонаукових методів, теоретичних та практичних підходів щодо аналізу творчості диригента. Автор використовував ретроспективний, системно-типологічний і порівняльний аналіз, а також аналіз вторинних даних, зібраних зі звітів, журналів та інших періодичних видань. Наукова новизна. 3 позиції мистецтвознавства здійснено комплексний аналіз творчого життя О. Кошиця, досліджено вплив української музики на світове мистецтво. Висновки. О. Кошиць, який жив за кордоном, записував українські мелодії в емігрантському середовищі та продовжував активну диригентсько-хорову діяльність, знайомлячи світ 3 мистецтвом України, завдяки своїй творчості здійснив вплив на мистецтво Європи та Америки.

Ключові слова: Олександр Антонович Кошиць; диригентське мистецтво; хорова культура.

Турчак Леся Ивановна, кандидат искусствоведения, Киевский университет культуры, ул. Е. Коновальца 36, Киев, Украина

Творчество А. А. Кошица в контексте мирового искусства

Цель работы. Выяснить место и роль творчества А. Кошица в контексте мировой культуры. Методология. Заключается в использовании общенаучных методов, теоретических и практических подходов к анализу творчества дирижера. Автор использовал ретроспективный, системно-типологический и сравнительный анализ, а также анализ вторичных данных, собранных из отчетов, журналов и других периодических изданий. Научная новизна. С позиции искусствоведения осуществлен комплексный анализ творческой жизни А. Кошица, исследовано влияние украинской музыки на мировое искусство. Выводы. А. Кошиц, который жил за границей, записывал украинские мелодии в эмигрантской среде и продолжал активную дирижерско-хоровую деятельность, знакомя мир с искусством Украины, благодаря своему творчеству оказал влияние на искусство Европы и Америки.

Ключевые слова: Александр Антонович Кошиц; дирижёрское искусство; хоровая культура.

Turchak Lesia, PhD in Art Criticism, Kyiv University of Culture, 36, Y. Konovaltsia St., Kyiv, Ukraine

O. A. Koshyts' creative activity in the context of world art

The purpose of the article is to find out the place and role of $\mathrm{O}$ Koshyts creative activity in the context of the world culture. Methodology of the study consists in the use of general scientific methods, theoretical and practical approaches to the analysis of the conductor's creative work. The author addressed to a retrospective, system and typological, and comparative analysis, as well as the analysis of the secondary data obtained from reports, journals and other periodicals. Scientific novelty. From the art history position there was carried out a comprehensive analysis of $\mathrm{O}$. Koshyts creative life, as well as a research of the Ukrainian music influence on the world art. Findings. O. Koshyts, living abroad, recorded Ukrainian melodies in the emigrant environment and continued his active conducting and choral activities, thus introducing the art of Ukraine to the world one, thus influencing the art of Europe and America. 
ISSN 2410-1176 (Print) Вісник КНУКіМ. Серія Мистецтвознавство. Вип. 39. ISSN 2616-4183 (Online)

Key words: Oleksandr Koshyts; conducting art; choral culture.

Вступ. Українська культура багата талановитими людьми, слава про яких відома на весь світ. Однак система дослідження їх діяльності та вкладу в світове мистецтво містить прогалини, а саме: невелика кількість досліджень, присвячених їх творчості за кордоном.

Українські митці розсіяні по всьому світу, відомі далеко за межами України, на все життя зберегли частинку рідного краю, закарбованого в мистецтві, зокрема й музичному. Одним 3 них був видатний вітчизняний хоровий диригент, композитор і етнограф Олександр Кошиць.

Чимало робіт присвячено українським митцям, які працювали за кордоном, до них належать: Голубець М. (Монографія 1920р. про творчість О. Архипенка), Нємцова В .С. (стаття: «Українське коріння творчості Давида Бурлюка»), Книш I. («Жива душа народу» книга про творчість В. Авраменка»), Тарасенко О. (стаття «Давньоруська ікона i супрематизм Казимира Малевича»), Цвіль В. (книга «Невідомий Кандинський») та ін.

Проте, залишилась ще недостатньо з'ясованою творчість багатьох українців, які жили та працювали за кордоном, серед них і О. Кошиць.

Тож метою дослідження є з'ясування внеску вихідців з України в світове мистецтво.

Метою статті є дослідження творчості О. Кошиця в контексті світової культури та мистецтва.

Олександр Антонович Кошиць народився 31 серпня (12 вересня) 1875 р. в с. Ромашки Київської губернії (нині Миронівський район Київської області) у родині священика. У 1877 p. батько переїхав на нову парафію поруч із Шевченковою Кирилівкою - у село Тарасівку Звенигородського повіту, саме там пройшло дитинство диригента.

У 1884 р. О. Кошиць вступає до «Єпархіальної Бурси» в м. Богуславі (нині приміщення гуманітарного коледжу). У 1890 р. переходить на навчання до Київської духовної семінарії, яку закінчив з відзнакою. У 1901 р., одержавши диплом Академії і вчений ступінь кандидата богослов'я, він наважується змінити сімейні традиції і йде працювати в «акцизі», на цукроварню, а потім вчителювати.

У 1902 р. Кошиць їде до м. Ставрополя, де працює вчителем Духовної жіночої гімназії. Там же (у м. Ставрополь), Кубанський Статистичний Комітет запропонував (за рекомендацією Миколи Лисенка) здійснити поїздку по станицях Кубані з метою запису народної пісні.

Пісні збиралися з 1903 до 1905 рр. За спогадами дослідника, в роботі йому: «багато допомогло знайомство з народною піснею, попереднє записування іiі. Я знав, так би мовити, загальні схеми пісні, спосіб іiі музикального виразу, знав народну музичну мову, звороти іiі, думки, загальні архітектурні риси різних форм: пісні історичної, побутової, ритуальної, релігійної, бойової... Так що мені не давало труду схопити головне і була можливість звернути увагу на цікаві, характерні деталі пісні. Це все полегшувало роботу, робило враження на співаків, викликало довіру до мене й утворювало вигідний психологічний грунт для передачі пісні в мої руки: співаки бачили, що я кохаюсь в цих мелодіях, знали, що буде записано найменшу дрібничку, а через те й старались віддати пісню якнайкраще, нічого не пропустивши» (Кошиць, 1995, с. 246).

Кошиць записав та передав 400 записів Статистичному Комітету. Ця робота була удостоєна (у 1908 р.) Золотої медалі на Етнографічній господарській виставці Кубані. На жаль, всі зошити після їі закриття безслідно зникли. Лише невелику частину пісень маестро вдалося поновити за чернетками (Головащенко, 2011).

Повернувшись до Києва в 1904 р., Кошиць вчителював у гімназіях, керував хорами Духовної школи, Школи сліпих, Комерційної школи, хором студентів університету Св. Володимира. Потім він перейшов працювати до Музично-драматичної школи Миколи Лисенка і студіював композицію в проф. Г. Любомирського. 31911 р. диригент вів клас хорового співу в училищі, а згодом і в консерваторії.

У 1912 р. Кошиць був запрошений М. Садовським на посаду диригента театру, з його появою відбулися зміни в роботі оркестру та хору, сюди залучають нових співаків 
(M. I. Литвиненко-Вольгемут, Суховольського та ін.), згодом, відновили оперети: «Утоплена» та «Різдвяна ніч» М. Лисенка, «Роксолана» Д. Січинського, оперу «Сільська честь» П. Масканьї. Кошиць пише музику до п’єс «Дай серцю волю, заведе в неволю» М. Кропивницького, «Казка старого млина» С. Черкасенка та ін. (Головащенко, 2011).

У 1917 р. диригента запрошують до Музичної театральної Комісії, того ж року він одружився з колишньою студенткою та співачкою хору Тетяною Георгієвською, яка пізніше стала вокалісткою Українського національного хору, викладачем, а після 1944 р. куратором Українського культурного та освітнього центру у Вінніпезі (R.Klymasz, 2006).

Після проголошення Української Народної Республіки голова Директорії і Головний Отаман військ УНР Симон Петлюра вирішує презентувати Україну світові. 1 січня 1919 р. він запрошує до себе Олександра Кошиця та Кирила Стеценка, пропонує створити хорову капелу, підготувати з нею добірну програму і виїхати у велике гастрольне турне по світу.

Так, Українська Республіканська капела під керівництвом Олександра Кошиця розпочала гастролі країнами Свропи, а потім Північною та Південною Америкою (Головащенко, 2011).

Гастролі капели почалися в квітні 1919 р., першою була Чехія. Репертуар складався 3 народних пісень в обробці українських композиторів.

Згодом капела продовжувала гастролі в Австрії, Швейцарії, Франції, Бельгії, Голландії, Англії, Німеччині, Іспанії. У 1921 р. в Польщі iї було реорганізовано в Український національний хор.

Про те як прийняли хор в Свропі свідчать спогади Кошиця. Про виступ у Женеві він згадував: «Коли заспівали «Марсельєзу» в моєму аранжуванні, піднявся такий гвалт, що я перелякався. Панночки повискакували зі своїх місць і в екстазі ламали парасолі об естраду. У Берні, після концерту, коли я сів до авто й туди втягли вінок такого розміру, як я сам, студенти закидали мене квітами й до самого готелю бігли 3 криками за автомобілем» (Ноберт, 2016 ).

Після успішного турне Європою, хор вирушив до США. Там пройшли виступи в НьюЙоркському «Карнегі Холл». Наступні концерти відбулися в «Колосеумі» і в «Президентському Театрі», які американська публіка сприйняла не менш «гаряче», ніж європейська. Поважне видання «Times Herald» (5 грудня 1922p.) написало схвальну рецензію на виступ: «Ті, що не були на концерті, не можуть собі уявити, що вони втратили, бо в Даласі ніколи не було чогось подібного до цього хору» (Ноберт, 2016 ).

Колектив тричі виходив переможцем у щорічному конкурсі аматорів співу з чотирьох штатів, який влаштовувався газетою «Chicago Tribune». Газета відзначала, що за своєю злагодженістю, чистотою тону це є один з найкращих хорів в Америці.

Упродовж лише трьох місяців, 3 жовтня по грудень 1922 p., Український Національний Хор гастролював у Північній Америці, виступивши у Нью-Йорку, Вашингтоні, Річмонді, Детройті, Клівленді, Чикаго, Колумбії, Тулсі, Оклахомі, Мемфісі і Далласі. У деяких містах - по кілька разів (Ноберт, 2016).

Після виступів у США хор вирушає до Аргентини, Бразилії та Мексики. У Мексиці українців не відпускали, хор дав втричі більше виступів, ніж планувалося. На концерті в Мехіко-сіті 26 грудня 1922 р. виступ відвідало 32600 осіб, диригентові пропонували державну підтримку задля того, щоб він оселився у Мексиці й зайнявся мексиканською народною піснею (Лютий, 2009).

Незважаючи на успіх у багатьох країнах Кошиць прагнув повернутися до України. Починаючи $з$ середини 1920-х, диригент пише листи до радянських установ 3 проханнями щодо повернення. Та безпрецедентний європейський резонанс, спричинений «хоровими диверсіями» диригента, йому не пробачили. У той час, коли дозвіл на повернення отримали Грушевський і Винниченко, кандидатуру Кошиця не було затверджено (Лютий, 2009).

У 1926 р. О. Кошиць залишається в США, оселившись неподалік від Нью-Йорка, керує хором (аматорським), а також принагідно диригує так званою «Сімкою» (сім українських церковних хорів 3 околиць Нью-Йорка), пише хорові твори, обробки 
ISSN 2410-1176 (Print) Вісник КНУКіМ. Серія Мистецтвознавство. Вип. 39. ISSN 2616-4183 (Online)

українських народних пісень. У 1933 р. нью-йоркська фірма «Wittmarc’n’son» («Вітмарк і син») мільйонним накладом видала сорок дві українські народні пісні в обробці Кошиця 3 англійським текстом (Лютий , 2009).

Однак, (на думку М. Головащенка) сталося так, що ні українська громада США, ні державні чиновники не змогли належно оцінити геній Кошиця і відповідно використати його величезний талант і досвід для майбутнього розвитку музичного мистецтва (КоротяКовальська, 2008).

Зміни відбулися лише в 1941 р., коли один з відомих керівників Осередку Української Культури й Освіти в Канаді, доктор мистецтвознавства Павло Маценко запросив Кошиця до Вінніпега вести клас хорового диригування і читати лекції з теорії та історії музики на новостворених диригентсько-вчительських курсах аби готувати керівників хорів для українських громад у різних провінціях та країнах.

Тут О. Кошиць здійснив мрію - залишив для нащадків звукозаписи українських пісень. Десять платівок, 27 записаних пісень, які представляють усі жанри української пісні, це: «Щедрівки та колядки дохристиянського періоду, історичні, героїчні, військові (стрілецькі), балади, побутові, любовні, сімейні, колискові, жартівливі, сатиричні, гумористичні та пісні до танцю (коломийки)... Пісні з Великої України, з Галичини та Буковини» (Жадько, 2012).

21 вересня 1944 р. український диригент захворів і помер у Вінніпезі. Його поховали в колумбарії цвинтаря «Глен-Іден» (Glen Eden) неподалік від Вінніпега. Близько 5 тисяч українців прийшли попрощатися 3 ним.

О. Кошиця.

Через рік українська молодь у Вінніпезі створила хор, який згодом отримав ім'я

Хор імені Кошиця продовжує діяльність як хор молоді Українського національного об’єднання. 1967 р. перейменовано на Хор ім. Олександра Кошиця. Унікальним є те, що відомий диригент привніс в хорове мистецтво низькі чоловічі голоси (баси). 31951 р. хором керував учень О. Кошиця - В. Г. Климків. 31978 р. хор неодноразово виступав з концертами в УРСР. А в 1992 р за популяризацію українського хорового мистецтва присуджена Державна премія України ім. Т. Шевченка.

Кошиць, як хоровий диригент, продемонстрував світу культурне багатство українського народу. Західноєвропейські музичні критики дали високу оцінку українській Капелі і відзначили талант іiї диригента: «Нема на світі нікого іншого, хто б у такій високій майстерній мірі, як Кошиць, володів мистецтвом трактувати хор, як музичний інструмент або оркестр, 3 якого він з безмежним артизмом уміє видобути всі звукові проміння», так писала швейцарська газета «Basler Anzeiger» у 1919 р. (Завітневич, 1972).

Диригент назавжди зберіг у своєму серці прихильність до самобутнього українського музичного фольклору. Справою свого життя він вважав збереження хорової культури, розвиток пісенного мистецтва та рідної мови. Створена ним хорова капела відрізнялася красою і багатством голосів, особливо басів. Слухачів Свропи та Америки підкорили глибокі й потужні пісенні образи, краса українських мелодій. Європа і Америка відкрили для себе справжню українську культуру.

Органічний зв'язок зі своїм народом, з рідною землею вплинув і на композиторську діяльність О. Кошиця. Глибоко розуміючи душу свого народу, Маестро досконало розвинув iii невичерпні музичні багатства (Завітневич, 1972).

Чимало часу Кошиць присвятив етнографічним дослідженням, результатом яких стали як наукові роботи, так і канти - церковні або світські пісні для триголосного ансамблю чи хору.

Ще в грудні 1916 р. на концерті в м. Києві Кошиць представив пісню «Щедрик» М. Леонтовича. Мотиви слів «Щедрика» збереглися з дохристиянських часів, коли Новий рік святкували навесні разом з природою, що оживала. Композитор знайшов текст народної щедрівки та написав до нього музику. М. Леонтович працював над своїм твором майже все життя. А сам «Щедрик» мав 5 авторських редакцій, перша 3 яких з'явилася в 1901 р., остання - 1919 р. Справжній прорив наступив тоді, коли в 1921 р. «Щедрик» прозвучав у 
виконанні Українського Хору під керівництвом О. Кошиця в Карнегі Хол у Нью-Йорку.

Ця мелодія настільки сподобалася американцям, що в 1936 р. співробітник NBC українського походження П. Вільховський (1902-1978рр.) написав англійські слова (які не базувалися на українській редакції) на мелодію «Щедрика». 3 тих пір ця пісня в Америці стала відома під назвою «Carol of the Bells» (2011).

Мелодія нагадувала Вільховському передзвін і він зафіксував цей образ у своїх віршах. Пізніше пісня закріпилася в музичній культурі Заходу під назвою «Колядка дзвонів» (англ. Carol of the Bells). До сьогоднішнього дня американські хори, професійні та аматорські, співають цей твір як колядку на Різдво.

Український «Щедрик» відповідає визначенню щедрівки, натомість, англійський зміст «Carol of the Bells» (інша назва - «The Little Swallow») визначає його як колядку, або, інакше кажучи, Різдвяну пісню.

Хори, зокрема й міський шкільний хор П. Вільховського, почали співати американську інтерпретацію «Щедрика» по всій країні. Протягом наступних двох декад «Carol of the Bells» виконувався мільйони разів і був здійснений переклад різними мовами. Сьогодні «Carol of the Bells» стала мелодією Різдва. Версія П. Вільховського не єдина, хоча їі можна вважати найуспішнішою. Існує версія М. Л. Холмана «Ring, Christmas Bells» 1947 p., дві пісні анонімних авторів, ще одна під назвою «Come, Dance and Sing», написана в 1957 р. (2011).

Багато варіацій «Carol of the Bells» презентовано в різдвяних альбомах найпопулярніших виконавців. Так український «Щедрик» став унікальним явищем світової культури та завдяки нашому співвітчизнику Кошицю потрапив за кордон і набув світової популярності.

Кошиць часто звертався й до доробку інших композиторів, представників аналогічного напряму в опрацюванні народних пісень, - О. Ступницького, Я. Яциневича, П. Демуцького, Ф. Попадича та ін. У своїх власних композиціях він дотримувався принципу виходу за межі «примітивного етнографізму», створюючи авторські обробки. Допомагали виникненню оригінальних музичних замальовок драматизація образної системи («Журавель», «Біда», «Гей, у полі та криниця безодня», «Чайка» та ін.), контрапунктичне поєднання двох різних пісень - «Журба» і «Косив козак сіно» - в одне художнє ціле, своєрідне трактування древніх релігійних наспівів (канти про «Почаївську Божу Матір», «Святу Варвару», літургії тощо) (Загайкевич, 2010).

Заслуги керівника українського національного хору Кошиця, якого називали «найліпшим диригентом» - очевидні. Керування хоровим колективом - справа дуже відповідальна, адже в колективі багато чого залежить від керівника-диригента.

Виступи хору під керівництвом Кошиця змусили американців звернути увагу на розвиток акапельного співу, якого раніше там майже не існувало. Обробки українських пісень, які видані з англійським текстом, розійшлися мільйонами примірників, диригент написав декілька томів спогадів про гастролі капели (Коротя-Ковальська, 2008).

Пам'ять про відомого українця збереглася не лише завдяки книгам, виданням, хору, музичним обробкам. У Канаді Кошицю встановлено бюст, у США - пам'ятник. За радянських часів ім'я талановитого українця не згадували, але 3 набуттям Україною Незалежності його ім'я і творчість повертаються до рідного краю.

У 2000 р. для увічнення пам'яті диригента в Тарасівці (Черкаська обл.) відкрито меморіальну стелу.

Наукова новизна. 3 позиції мистецтвознавства здійснено комплексний аналіз творчого життя Кошиця, досліджено вплив української музики на світове мистецтво.

Висновки. Незважаючи на те, що О. Кошиць знаходився далеко за межами України, він записував українські мелодії в емігрантському середовищі та продовжував активну диригентсько-хорову діяльність, знайомлячи світ 3 культурно-мистецькими скарбами України. Вважається, що за основу для написання арії «Summertime» для опери «Porgy and Bess» Дж. Гершвін взяв українську колискову «Ой, ходить сон коло вікон», яку він почув у Нью-Йорку у виконанні Українського Національного Хору під керуванням О. Кошиця. 
ISSN 2410-1176 (Print) Вісник КНУКіМ. Серія Мистецтвознавство. Вип. 39. ISSN 2616-4183 (Online)

Кошиць полонив світ українською піснею, завдяки диригенту українська культура та мистецтво стали відомі в світі. Таким чином відбулось не лише знайомство з українською культурою, а й вплив іiі на світове музичне мистецтво, українська та світова культура збагатилася новими мелодіями.

Посмертно Олександр Кошиць залишив музичну спадщину. Його особистий i музичний архів знаходиться в Осередку української культури і освіти у Вінніпезі.

\section{Список використаних джерел}

1. Александр Антонович Кочии. По мемуарным источникам. URL: http://www.mos-ukrcapella.ru/koshic.php/. (дата звернення: 13.10.2018).

2. Головащенко М. Феномен Олександра Кошиия. Київ: Музична Україна, 2007. 576 с.

3. Головащенко М. Олександр Кошиць і його хор як вісник світової слави української пісні. Наша Парафія : [сайт]. Київ, 2011. URL: https://parafia.org.ua/person/koshyts-oleksandr/. (дата звернення 08.11.2018).

4. Данилова Т. В. Філософські ідеї в східнослов'янських рецепиіях пам'ятки «Стефаніт і Іхнілат». Ніжин: Видавець Лисенко М. М., 2013. 156 с.

5. Жадько В. Де ж похований Олександр Кошиць? Кримська світлиия : [сайт]. 2012. №12. URL: http://svitlytsia.crimea.ua/?section=article\&artID=11167. (дата звернення 08.09.2018).

6. Завітневич В. Гармонійний талант. Свобода. Украӥнський щоденник. 1972. 20 жовтня. С. 1-2. URL: http://www.svoboda-news.com/arxiv/pdf/1972/Svoboda-1972-195.pdf. (дата звернення 08.10.2018).

7. Загайкевич М. Мистецькі паралелі: велич і парадокси долі Олександра Кошиця та Василя Авраменка. Студї мистецтвознавчі. 2010. Вип. 3(31). С. 34-40.

8. Калуцка Н. Б., Пархоменко Л. О. Олександр Кошищь: мистещька діяльність у контексті музики ХХ сторіччя. Київ : Фенікс, 2012. 380 с.

9. Кошиць Олександр Антонович. Howling Pixel : [сайт]. 2018. URL:

https://howlingpixel.com/i-uk/i-uk/Кошиць_Олександр_Антонович (дата звернення 08.10.2018).

10. Кошиць О. Спогади. Київ: Рада, 1995. 378 с.

11. Коротя-Ковальська В. П. Украӥнська народнопісенна творчість в украӥнознавстві. Київ: НДІУ, 2008. 254 с.

12. Лютий I. Дипломат співу. Тиждень. 2009. 2 жовтня. URL: https://tyzhden.ua/History/3537 (дата звернення: 10.10.2018).

13. Норберт К. Іван. Світовий тріумф Українського Національного Хору Олександра Кошиця. Ukrainian people. 2016. URL: https://ukrainianpeople.us/світовий-тріумф-українськогонаціон/ (дата звернення: 12.11.2018).

14. Памятные даты. Ukrinform: [сайт]. 2017. 12 вересня. URL:

https://www.ukrinform.ru/rubric-society/2302803-12-sentabra-pamatnye-daty.html. (дата звернення: 13.10.2018).

15. Хортяні Я. Світ почув українську пісню. Громада. Товариство української культури в Угорщині : [сайт]. 2012. №2 (118) квітень-червень. URL:

http://hromada.hu/2012/nom_118/istorija/pisnya.html. (дата звернення 14.10.2018).

16. Festival of Carols. Oseredok News : [online]. 2016. Vol. 7., no. 3. URL: http://oseredok.ca/wp-content/uploads/2017/11/Visti-Vol.-7-No.-3.pdf. (Accessed: 14.10.2018).

17. Karas H. Oleksandr Koshytsya Choral Conducting School. Вісник Національної академії керівних кадрів культури і мистецтв. 2016. №3. С. 23-27.

18. Klymasz R. Ukrainian Music in Canada. Historica Canada : [online]. 2014. URL: https://www.thecanadianencyclopedia.ca/en/article/ukraine-emc/. (Accessed: 10.10.2018).

19. O. Koshetz Ukrainian Choir: [online]. URL:

http://www.koshetzchoir.org/our_history_timeline.html. (Accessed: 10.10.2018).

20. Shchedryk (song). WikiVisually: [online] 2018. URL:

https://wikivisually.com/wiki/Shchedryk_(song). (Accessed: 14.10.2018).

21. Simpson G.W. Alexander Koshetz in Ukrainian Music. Winnipeg : Ukr. Culturala Educational Centre, 1946. 3 p. 
22. Spurr S. Carol of the Bells Lyrics. Christmas Carols : [online]. 2011. URL: https://web.archive.org/web/20120328050901/http://carols.co/carol-of-the-bells/ 08.10.2018).

23. Toledo Opera. Porgy and Bess. Teacher's Guide and Resource Book. Toledo Opera, 2016. 29 p.

\section{References}

1. Alexander Antonovich Koshetz. By memoir source. Available at: <http://www.mos-ukrcapella.ru/koshic.php Pfujk/> [Accessed 13 October 2018].

2. Golovashchenko, M., (2007). Fenomen Oleksandra Koshytsia [The phenomenon of Olexander Koshetz]. Kyiv: Muzychna Ukraina.

3. Golovashchenko, M., (2011). Oleksandr Koshyts i yoho khor yak visnyk svitovoi slavy ukrainskoi pisni [Olexander Koshetz and his chorus as the herald of the world fame of Ukrainian songs]. Our Parish. Available at: <https://parafia.org.ua/person/koshyts-oleksandr/> [Accessed 08 November 2018].

4. Danylova, T.V., (2013). Filosofski idei v skhidnoslov'ianskykh retseptsiiakh pam'iatky «Stefanit i Ikhnilat» [Philosophical Ideas in the East-Slavic Receptions of the "Stefanit and Ichnilat" manuscript]. Nizhyn: Publisher Lysenko M.M.

5. Zhadko, V., (2012). De zh pokhovanyi Oleksandr Koshyts? [Where is Oleksandr Koshetz buried?]. Crimean svitlytzia, issue 12. Available at:

<http://svitlytsia.crimea.ua/?section=article\&artID=11167> [Accessed 8 September 2018].

6. Zavinetnevich, V., (1972). Harmoniinyi talant [Harmonious talent]. Svoboda. Ukrainian Diary, 20 Oct. pp. 1-2. Available at: <http://www.svoboda-news.com/arxiv/pdf/1972/Svoboda1972-195.pdf> [Accessed 8 October 2018].

7. Zahaykevych, M., 2010. Mystetski paraleli: velych i paradoksy doli Oleksandra Koshytsia ta Vasylia Avramenka [Artistic parallels: greatness and paradoxes of the fate of Oleksandr Koshetz and Vasyl Avramenko]. Art studies, issue 3(31), pp. 34-40.

8. Kalutska, N.B., Parkhomenko, L.O., 2012. Oleksandr Koshyts: mystetska diialnist u konteksti muzyky XX storichchia [Oleksandr Koshetz: Artistic activity in the context of music in the $20^{\text {th }}$ century]. Kyiv: Phoenix.

9. Koshetz Oleksander Antonovich, 2018. Howling Pixel. Available at: <https://howlingpixel.com/i-uk/i-uk/Кошиць_Олександр_Антонович> [Accessed 8 October 2018].

10. Koshetz, O., 1995. Spohady [Memoirs]. Kyiv: Rada.

11. Korotia-Kovalska, V.P., 2008. Ukrainska narodnopisenna tvorchist v ukrainoznavstvi [Ukrainian folk-song art in Ukrainian studies]. Kyiv: NDIU.

12. Liutyi, I., 2009. Dyplomat spivu [Diplomat of singing]. Tyzhden, 2 Oct. Available at: <https://tyzhden.ua/History/3537> [Accessed 10 October 2018].

13. Norbert K. Iwan, 2016. Svitovyi triumf Ukrainskoho Natsionalnoho Khoru Oleksandra Koshytsia [The world triumph of O. Koshetz Ukrainian National Choir]. Ukrainian people. Available at: <https://ukrainianpeople.us /світовий-тріумф-українського-націон/ [Accessed 12 November 2018].

14. Pamjatnye daty [Memorable dates], 2017. Ukrinform. 12 Sept. Available at: <https://www.ukrinform.ru/rubric-society/2302803-12-sentabra-pamatnye-daty.html> [Accessed 13 October 2018].

15. Hortyani, Ya., (2012). Svit pochuv ukrainsku pisniu [The world heard the Ukrainian song]. Community. Ukrainian Culture Society in Hungary, issue 2(118), April-June. Available at: <http://hromada.hu/2012/nom_118/istorija/pisnya.html> [Accessed 14 October 2018].

16. Festival of Carols, 2016. Oseredok News, vol. 7, no. 3. Available at: <http://oseredok.ca/wp-content/uploads/2017/11/Visti-Vol.-7-No.-3.pdf> [Acessed 14 October 2018].

17. Karas, H., (2016). Oleksandr Koshytsya Choral Conducting School. National Academy of Managerial Staff of Culture and Arts Herald, is.3, pp. 23-27.

18. Klymasz, R. (2014). Ukrainian Music in Canada. Historica Canada. Available at: <https://www.thecanadianencyclopedia.ca/en/article/ukraine-emc/> [Accessed 10 October 2018].

19. O. Koshetz Ukrainian Choir, Available at: 
ISSN 2410-1176 (Print) Вісник КНУКіМ. Серія Мистецтвознавство. Вип. 39. ISSN 2616-4183 (Online)

<http://www.koshetzchoir.org/our_history_timeline.html> [Accessed 10 October 2018].

20. Shchedryk (song), 2018. WikiVisually. Available at:

<https://wikivisually.com/wiki/Shchedryk_(song)> [Accessed 05 August 2018].

21. Simpson, G.W. (1946). Alexander Koshetz in Ukrainian Music. Winnipeg: Ukr. Culturala Educational Centre.

22. Spurr, S. (2011). Carol of the Bells Lyrics. Christmas Carols. Available at:

<https://web.archive.org/web/20120328050901/http://carols.co/carol-of-the-bells/> [Accessed 08 October 2018].

23. Toledo Opera. Porgy and Bess. Teacher's Guide and Resource Book, (2016). Toledo Opera.

(C) Турчак Л. М., 2018

Стаття надійшла до редакиії: 31.11.2018

УДК 780.614:37.091.33

Яницький Тарас Йосипович,

Заслужений артист Украӥни,

доцент кафедри музичного мистецтва,

Київський Національний університет

культури і мистецтв,

вул. С. Коновальия,36, Київ, Украӥна, 01133, https://orcid.org/0000-0003-3320-4088, yanitskiy@gmail.com

\section{ОСОБЛИВОСТІ МЕТОДИКИ ВИКЛАДАННЯ ГРИ НА БАНДУРІ Я. Г. ПУХАЛЬСЬКОГО}

Мета роботи. Дослідити особливості викладання в бандурній педагогіці, поряд із узагальненою методикою сучасного викладання на інших інструментах, зокрема на гітарі, як щипковому інструменті. Правильна постановка апарата музиканта, його технічний розвиток, розглядається як детермінанта відтворення художнього змісту виконуваного музичного твору. Методологія дослідження. Поєднуються методи біографічного опису, аналізу актуальних педагогічних проблем у викладанні гри на бандурі та систематизації основних виконавських принципів у навчальному процесі. Наукова новизна полягає у виявленні основних принципів та методів підвищення виконавської майстерності в зв'язку 3 еволюційним шляхом розвитку бандури і її репертуару, в контексті виконання оригінальних творів та транскрипцій-перекладень, які запропонував Я.Г. Пухальський. Висновки. Зазначається, що утвердження та розвиток навичок застосування перенесення лівої руки на приструнки (бандура київського типу), відкриває широкі можливості для виконання складних поліфонічних творів. Набуття технічної досконалості, що складається 3 цілого комплексу необхідних елементів, дає можливість виконавцю точно відтворити звукову, ритмічну, динамічну та інші сторони музичного твору. Констатується, що розширення діапазону на існуючому інструменті шляхом додавання приструнків, автор тлумачить як прогресивний шлях від кобзи до бандури.

Ключові слова: звуковидобування; техніка; удар; щипок; виконавська майстерність; транскрипція-переклад.

Яницкий Тарас Иосифович, заслуженый артист Украины, дочент кафедры музыкального искусства, Киевский национальный университет культуры и искусств, ул. Е. Коновальиа, 36, Киев, Украина

Особенности методики преподавания игре на бандуре Я. Г. Пухальского

Цель работы. Исследовать особенности методики преподавания в бандурной педагогике, наряду с общей методикой современного преподавания на других инструментах, в частности на гитаре, как щипком инструменте. Правильная постановка аппарата музыканта, его 